\title{
PENGUNGKAPAN SEKSUALITAS DIRI PADA MEDIA SOSIAL INSTAGRAM @SISILISM
}

\author{
Nirra Swastika ${ }^{1}$, Nanang Krisdinanto ${ }^{2}$, Brigitta Revia Sandy Fista ${ }^{3 *}$ \\ ${ }^{1,2,3)}$ Communication Science Department, Faculty of Communication Science, \\ Widya Mandala Surabaya Catholic University, Surabaya, Indonesia \\ *Penulis korespondensi; Email: gita@ukwms.ac.id
}

\begin{abstract}
ABSTRAK
Seksualitas pada diri individu cenderung disembunyikan dan tidak dibagikan. Penelitian ini fokus pada pengalaman dan pemaknaan subjek akan seksualitas sehingga dapat melakukan pengungkapan diri (self-disclosure) pada media sosial Instagram. Penelitian ini menggunakan pendekatan kualitatif, jenis penelitian deskriptif, serta metode penelitian fenomenologi dimana peneliti membiarkan subjek secara aktif membentuk makna melalui sisi intersubyektifnya yaitu pengalaman yang pernah terjadi terkait seksualitas. Teknik pengumpulan data dilakukan melalui wawancara mendalam untuk memperoleh hasil dari sudut pandang orang pertama, yakni Sisil. Dalam penelitian ini berhasil ditemukan bahwa Sisil memandang seksualitas sebagai kesenangan dan kenikmatan, sehingga ia berani melakukan pengungkapan diri dengan menceritakan pengalaman seksualitasnya di media sosial. Sisil melakukan pengungkapan di media sosial Instagram sebagai bentuk ekspresi diri untuk memenuhi kepuasannya dalam berbagi pengalaman.
\end{abstract}

Kata kunci: Self-disclosure, Seksualitas, Instagram, Fenomenologi, Pemaknaan.

\begin{abstract}
Sexuality in individuals tends to be hidden and not shared. This research will focus on experiences and the subject's meaning on sexuality thus can be done by self-disclosure in social media Instagram. Qualitative approach, descriptive type research, also phenomenology type research were used in this research thus researcher can make a meaning actively from the intersubjective side that is based on the sexuality experiences. Interview was used to gather the data to earn the deep information from the first person point of view from Sisil. From this research, it can be concluded that Sisil's view of sexuality as a pleasure and intimacy, which shapes her to self-disclosure by telling her sexual experiences on her social media platform. She did what she did on social media as a self expression to fulfil her enjoyment by sharing.
\end{abstract}

Keywords: Self-disclosure, Sexuality, Instagram, Phenomenology, Meaning.

\section{PENDAHULUAN}

Seseorang membutuhkan orang lain untuk berinteraksi dan bersosialisasi. Tidak dapat dipungkiri bahwa terkadang individu akan menyampaikan informasi tentang dirinya yang biasanya disembunyikan terkait pikiran, perasaan, bahkan perilaku. Devito (1997: 61) menjelaskan bahwa, bentuk komunikasi yang dilakukan sebagai self-disclosure (pengungkapan diri), yaitu penyampaian informasi yang cenderung ditutupi oleh pemilik informasi dan sebelumnya tidak diketahui oleh penerima, biasanya disembunyikan.

Temuan yang menarik dalam penelitian ini yaitu pengungkapan diri yang dilakukan ternyata tidak hanya terjadi pada komunikasi dan interaksi secara langsung antar manusia atau face-to-face, namun juga terjadi melalui perantara yaitu media sosial. Penelitian yang dilakukan oleh Duggan dan Brenner (dalam Chennamaneni dan Taneja, 2015: 1) menunjukkan bahwa 67 persen dari pengguna internet, menggunakan media sosial untuk berinteraksi satu dengan yang lainnya. Joinson, dkk (2011: 42) dalam penelitiannya juga menyebutkan bahwa pengguna media sosial secara konsisten terlibat dalam aktivitas pengungkapan diri di media sosial.

Al-Kandari, dkk (2016: 87) mengatakan bahwa pengguna Instagram dapat mengubah akunnya menjadi akun pribadi atau akun publik, sehingga mereka dapat mempersonalisasi profil mereka. Ketika pengguna telah menjadi pengikutnya, maka ia dapat melihat, menyukai, dan mengomentari apapun yang telah diunggah akun tersebut. Media sosial Instagram merupakan media pengungkapan diri lewat foto yang diunggah pada akun Instagramnya yang nantinya akan dimaknai sebagai suatu sistem nilai tertentu (Nurudin dalam Ayub, dkk, 2017: 3).

Bila pengungkapan diri memiliki arti bahwa secara sadar seseorang membocorkan sesuatu tentang dirinya yang bersifat pribadi atau rahasia, penelitian ini akan meneliti seorang pengguna media sosial Instagram yang menggunakan akun media sosialnya 
untuk membocorkan informasi tentang dirinya yang biasanya bersifat pribadi atau rahasia, yaitu @ sisilism. Dikatakan sebagai pribadi atau rahasia, karena Sisil pengelola akun Instagram @ sisilism - sering mengunggah unggahan bertema seksualitas.

Selain di media sosial Instagram, Sisil memiliki platform lain untuk membuat konten-konten terkait seksualitas, seperti YouTube, Twitter, dan TikTok. Dalam aktivitasnya di YouTube, Sisil membuat konten video dengan topik-topik yang telah ia tentukan, seperti pembahasan tentang kondom, ukuran penis, keamanan oral seks, lubrikan, pengalaman malam pertama, dan lain sebagainya. Berbeda dengan aktivitasnya di Instagram, Sisil dalam platform YouTube cenderung tidak melakukan aktivitas pengungkapan diri, melainkan lebih cenderung mengedukasi dengan mendatangkan tamu seorang dokter atau orang-orang yang ahli di bidangnya sebagai narasumber. Gambar I.1 adalah akun YouTube Sisil dengan jumlah subscriber sebanyak 193.000 dan jumlah unggahan sebanyak 68 video.

Sama halnya dengan YouTube, pada platform Twitternya Sisil pun cenderung tidak melakukan pengungkapan diri. Akun Twitternya cenderung digunakan untuk mengungkapkan keluh kesah atau sebagai tempat curahan hati. Gambar I.2 adalah akun Twitternya dengan jumlah pengikut 17.400 .

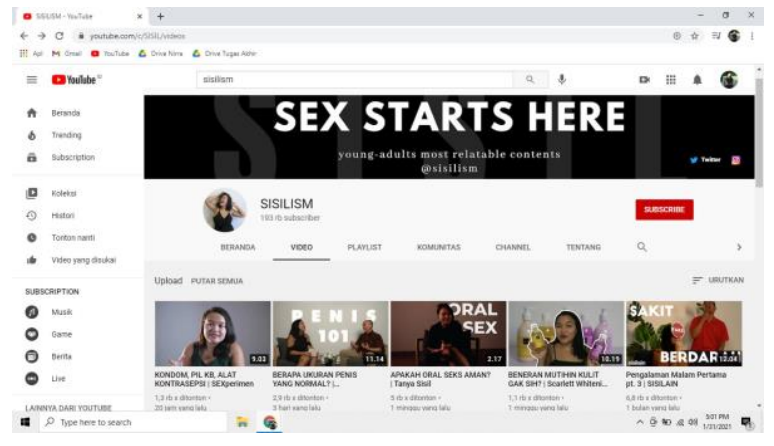

Gambar 1. Akun YouTube SISILISM (Sumber: YouTube)

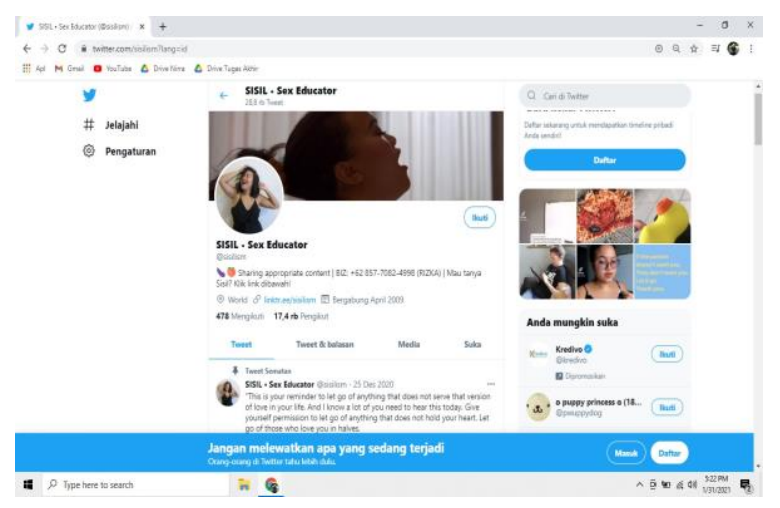

Gambar 2. Akun Twitter @ sisilism (Sumber: Twitter)
Selain Instagram, YouTube, dan Twitter, baru-baru ini Sisil mencoba media sosial yang sedang naik daun, yaitu TikTok. Pada media sosial TikTok ini, Sisil membuat konten edukasi serta hiburan yang masih ada kaitannya dengan seksualitas. Namun dari sekian banyak media sosial yang digunakan Sisil untuk membuat konten edukasi tentang seks, hanya di Instagram Sisil cenderung melakukan aktivitas pengungkapan diri dengan intensitas penggunaan yang cenderung sering. Itulah mengapa platform Instagram dipilih dari sekian media sosial lainnya. Di luar menyampaikan edukasi tentang seks, Sisil kerap memasukkan pengalaman-pengalamannya sehingga edukasi seks terdengar menjadi lebih provokasi.

Tirto.id (2018) dalam artikelnya berjudul Pengetahuan Seks adalah Tabu: Bikin Malu Sekaligus Penasaran menuliskan adanya hasil survei yang diselenggarakan situs BabyChild terhadap 1.700 orang tua anak usia 5-11 tahun. Hasilnya adalah 59 persen dari mereka tidak setuju dengan adanya pendidikan seks untuk anak dengan alasan tidak pantas menyampaikan kepada buah hati mereka. Dikatakan dalam buku milik Wijana dan Rohmadi (2013: 111), tabu merupakan sesuatu yang menakutkan, tidak mengenakkan perasaan, tidak santun, dan tidak pantas. Di Indonesia, isu-isu terkait seksualitas yang seharusnya penting, malah dianggap tabu untuk dibicarakan di ranah publik.

Sisil merupakan seorang pengguna Instagram dengan jumlah pengikut, yaitu 72 ribu pengikut dengan topiknya, yaitu seksualitas. Sisil menggunakan fitur Instastory, Instagram TV, dan Instagram feeds dalam membicarakan isu seksualitasnya. Menjadi menarik bagi peneliti karena media sosial pada dasarnya digunakan oleh banyak orang, sedangkan @ sisilism banyak sekali menceritakan informasi terkait dirinya, terutama yang sering dianggap tabu orang banyak orang.

Gambar I.2 merupakan salah satu unggahan Sisil pada salah satu Instastory-nya yang menjelaskan bahwa benda yang sedang dipegangnya (baca: dildo) merupakan benda yang penting bagi perempuan, karena Sisil menganggap bahwa vagina juga memerlukan pijatan. Padahal, Wardhaugh (2006: 230) menyebut vagina merupakan salah satu organ genital yang tabu untuk disebutkan. Selain penyebutan alat kelamin, Sisil dalam unggahannya juga sempat mendefinisikan atau menjelaskan rasa, sensasi, serta kenikmatan yang akan diterima oleh perempuan ketika vaginanya dipijat oleh benda tersebut. Selain itu, Sisil juga menyebutkan pentingnya orgasme bagi perempuan. 


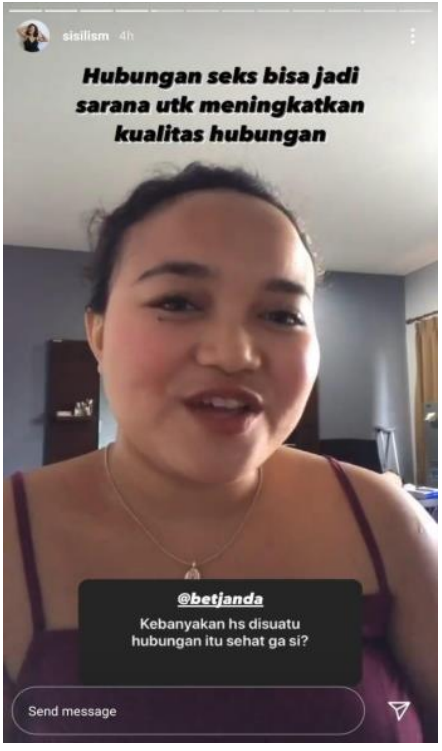

Gambar 3. Instastory @sisilism (Sumber: Instagram)

Pada gambar I.3, Sisil menjawab salah satu pertanyaan mengenai pengaruh terlalu banyak berhubungan seks pada kesehatan. Dalam Instastory yang berbentuk video itu, Sisil menganggap bahwa berhubungan seks adalah sesuatu hal yang indah, bahkan dapat menjadi sarana dalam meningkatkan kualitas hubungan. Telah diketahui sebelumnya, bahwa seks merupakan hal yang tabu di Indonesia, namun pada media sosial Instagram @ sisilism, Sisil mengupas, menjelaskan, serta bercerita mengenai seks dengan begitu terbuka.

"Well, I'm a high risk taker. Jadi gue memang suka mengambil risiko and noo, gue nggak bilang ke orang tua, ya. I mean yang gini-gini biasanya gue keep buat diri gue sendiri. Bahkan pertama kali mereka tau, ya kaget juga, bahkan nggak nerima. Tapi yaudah lama-lama gue bodo amat sama opini orang dan akhirnya keluarga ujung-ujungnya nerima juga, sih. Yes. Gue tipe yang mudah terbuka sama orang lain, keluarga juga. Tapi mereka tidak terlalu bisa menerima dengan lapang dada. Cuma, ya gimana? Ujungujungnya mereka akan terima juga, sih." (Sisil, 19 November 2020)

Kutipan percakapan di atas merupakan ungkapan dari Sisil terkait keterbukaannya dalam hal seksualitas. Berdasarkan pernyataan yang disampaikan di atas, Sisil menjelaskan bahwa keputusannya dalam mengungkapkan informasi memang didasari oleh dirinya yang berani mengambil risiko. Padahal, self-disclosure memiliki risiko pula (Acquisti dan Gross, 2006: 37), yaitu tersebarnya informasi dan terganggunya privasi pemilik informasi yang menyebabkan cyberbullying, pengawasan, dan pencurian informasi.
Namun perlu diketahui bahwa terdapat pula beberapa alasan yang membuat seseorang memutuskan untuk menutup informasi privat, yaitu takut keberadaannya ditolak oleh orang di sekitar. Individu seringkali menyembunyikan informasi terhadap orang lain ketika kebutuhan individu tersebut untuk terbuka adalah rendah (West \& Turner, 2010: 196).

Hal-hal inilah yang menjadikan pengungkapan diri pada media sosial Instagram @ sisilism menarik untuk diteliti, karena hal-hal yang biasa dianggap tabu oleh masyarakat, bahkan disembunyikan dan dirahasiakan, malah diungkapkan dengan sangat terbuka.

Petronio (2002: 3) menyatakan bahwa individu yang merasa menjadi pemilik utama dari informasi dapat mengontrol atas apa, kapan, dan kepada siapa informasi pribadi tersebut dibagikan. Ketika individu membuat keputusan untuk membuka atau menutup informasi privat individu tersebut memiliki kriteria tertentu. Dengan mengunggah konten-konten tabu di media sosial, banyak kemungkinan-kemungkinan buruk serta risiko yang diterima, seperti stigma buruk akan diri individu tersebut, konflik antar relasi, kehilangan pekerjaan, bahkan hambatan kerja (Romo, 2017: 174).

Communication privacy management (CPM) merupakan teori komunikasi yang menjelaskan proses pengungkapan diri baik dalam lingkungan sosial atau internet (Petronio dalam Chennamaneni dan Taneja, 2015: 2). Teori ini akan menjelaskan bagaimana individu mengungkapkan dirinya serta mengelola batas privasi mereka akan informasi pribadi. Menarik bagi peneliti sebenarnya bagaimana informasi pribadi seseorang yang disampaikan melalui media sosial yang dapat dikonsumsi oleh banyak orang. Sosial media kini menyediakan lahan bagi seseorang untuk menemukan teman baru, menjalin hubungan yang baik dengan teman, keluarga, dan masih banyak lagi. Gaya komunikasi kini semakin mudah dan cepat dengan adanya computer-mediated communication (CMC). CMC diartikan sebagai komunikasi atau pertukaran informasi yang dilakukan lewat jaringan komputer (Tomic dalam Astuti, 2011: 217-218).

Penelitian ini akan terfokus pada pengungkapan diri individu mengenai informasi dirinya yang berkaitan tentang seks yang dilakukan di media sosial Instagram dengan jumlah pengikut yang terbilang banyak. Penelitian kali ini menggunakan pendekatan kualitatif dengan jenis penelitian fenomenologi. Peneliti memilih menggunakan metode penelitian kualitatif karena fokus pada pengungkapan diri akun @ sisilism 
di Instagram dan proses pengumpulan data nantinya peneliti akan mengamati serta wawancara yang kemudian dituangkan dalam bentuk laporan berupa gambar dan kata-kata. Pendekatan yang dipilih adalah fenomenologi dengan tujuan menggambarkan makna dari pengungkapan diri Sisil pada akun Instagram @ sisilism yang digali melalui pengalaman Sisil dan peneliti membiarkan subjeknya menyampaikan pengalaman serta pemaknaan tanpa memaksa jawaban yang akan disampaikan benar atau salah, melainkan netral.

\section{LITERATURE REVIEW}

Adapun penelitian sebelumnya mengenai self-disclosure yang telah dilakukan oleh Apolonaris Davianus (2019) tentang Studi Fenomenologi Self-disclosure PSK terhadap Anak.Penelitian tersebut berfokus pada pengungkapan diri PSK terhadap anak. Para PSK dalam interaksi sehari-harinya cenderung untuk menutupi pekerjaannya kepada keluarga dan anak karena didasari ketakutan serta malu bila diketahui dirinya adalah seorang PSK. Informasi tersebut berusaha untuk dirahasiakan dengan adanya pengungkapan diri demi menjaga perkembangan hubungan agar tetap ada derajat keintiman hubungan antara ibu dan anak.

Selanjutnya, penelitian yang lain terkait Self-disclosure adalah Self-disclosure Individu pada Aktivitas Kencan Online (Studi pada Individu di Jejaring Sosial Facebook) yang diteliti oleh Yeanita Lestarina (2012) mahasiswa Fakultas Ilmu Sosial dan Ilmu Politik, Universitas Indonesia. Penelitian tersebut ditujukan guna menjelaskan pengungkapan diri individu saat melakukan kencan online di Facebook. Pada hasilnya, individu pelaku kencan online merasa lebih nyaman dalam berkomunikasi secara online dibanding offline. Terdapat perbedaan pula pada keluasan serta kedalaman topik antara pria dan wanita saat awal hubungan atau setelah berjalan lebih lama.

Meninjau dari penelitian-penelitian terdahulu yang disebutkan sebelumnya, dari berbagai segi yaitu objek, subjek, serta metodologi, peneliti menemukan kebaruan yang disajikan dalam penelitian ini. Pada subjek penelitian dipilih sangat berbeda, yaitu salah satu pengguna media sosial Instagram yang terbilang memiliki banyak pengikut dan salah satu topik yang sering diangkatnya adalah seks yang masih dianggap tabu di Indonesia.

Dalam konsep Self-disclosure atau pengungkapan diri (Devito, 1997: 61) mengatakan konsep self-disclosure biasanya digunakan untuk mengungkapkan informasi yang secara sadar. Devito (1997: 62) menjelaskan bahwa adanya faktor-faktor yang mempengaruhi self-disclosure, yaitu besaran kelompok, perasaan menyukai, efek diadik, kompetensi, kepribadian, topik, dan jenis kelamin. Meminjam pemikiran Derlega, dkk (dalam Devito, 1997: 62) kita akan membuka diri pada orang-orang yang disukai dan kita percayai. Pengungkapan diri ini juga dilakukan bila orang yang ada bersama dengan kita juga melakukan pengungkapan diri. Hal ini akan menimbulkan rasa aman, nyaman, dan memperkuat perilaku pengungkapan diri.

Faktor berikutnya adalah kompetensi. Orang yang merasa dirinya kompeten akan merasa percaya diri yang diperlukan untuk lebih memanfaatkan selfdisclosure. Serta orang-orang yang pandai bergaul, akan lebih banyak melakukan pengungkapan diri ketimbang orang-orang yang kurang berani bicara. Pengungkapan diri biasanya mengungkapkan informasi diri mengenai pekerjaan atau hobi, ketimbang kehidupan seks. Umumnya, makin pribadi dan makin sensitif topik yang diangkat, maka akan semakin kecil pula kemungkinannya dalam pengungkapan diri.

Meminjam pemikiran dari Petronio (2002: 2), communication privacy management (CPM) menjelaskan mengenai seseorang pada dasarnya membuat pilihan antara mengungkapkan atau menyembunyikan informasi privat berdasarkan syarat serta kondisi tertentu terkait akses ke informasi-privat tersebut.

Sandra Petronio menggunakan istilah 'boundaries' untuk menggambarkan adanya batasan pada setiap pesan yang diberikan oleh pemilik pesan (owner) kepada penerima pesan (co-owner). Dalam bukunya, Petronio juga menjelaskan adanya lima asumsi dasar dari CPM, yaitu private information, boundaries, control and ownership, rule-based management system, dan management dialectics (Petronio, 2002: 4). Private information yang dimaksud adalah hal-hal yang sifatnya privat dan dirahasiakan oleh pemilik pesan dari lingkungan sekitarnya. Pemilik pesan akan memberikan informasi privatnya kepada orang lain bila ada rasa keintiman (intimacy). Keintiman yang dimaksud meliputi rasa memahami secara mendalam baik dari sisi fisik, emosional, psikologis, dan behavioral kepada seseorang (Petronio, 2002: 6).

\section{METODE PENELITIAN}

Penelitian ini menggunakan metode penelitian fenomenologi karena subjek penelitian ini, yaitu Sisil sebagai pengelola akun Instagram @sisilism akan secara aktif membentuk makna dari konten yang diangkat. Sisil sebagai pengelola akun Instagram @ sisilism yang tinggal di Bali saat ini berusia 24 tahun dan aktif menjadi pembuat konten di Instagram 
mengenai hal-hal yang dianggap tabu di masyarakat, yaitu seks. Pemilihan subjek penelitian ini melalui banyak pertimbangan, salah satunya dikarenakan Sisil menurut peneliti dapat menyampaikan informasi apa adanya, tidak ada yang disembunyikan.

Realita dalam kegiatan sehari-harinya ialah salah satu hal yang terpenting dalam pembentukan makna oleh subjek penelitian. Penelitian fenomenologi mengutamakan perspektif subjek penelitian berdasarkan dengan apa yang dilihat dan didapatkan, bukan dari perspektif dan idealisme peneliti terhadap fenomena yang akan diteliti (Barnawi dan Darojat (2018: 101).

Husserl (dalam Barnawi dan Darojat, 2018: 102) berpendapat bahwa semua orang memiliki kebenarannya masing-masing dan dapat dicapainya sendiri. Melalui pendapat ini, fenomenologi bisa membantu peneliti dalam melihat Sisil dalam pengungkapan dirinya sebagai pembelajaran mengenai sifat dan makna konten yang tabu pada akun Instagramnya.

Analisis data dalam penelitian ini akan dilakukan merujuk pada Van Kaam dalam Kuswarno (2009:69) yaitu tahapan proses reduksi data, penyajian data dan verifikasi data sebagai berikut:

a. Reduksi data dilakukan dengan memilih dan mengkategorisasikan data yang didapat dari wawancara dengan informan.

b. Informasi yang telah dipilih kemudian disajikan untuk kemudian dilakukan penarikan kesimpulan. (penarikan kesimpulan ini disebut verifikasi data, yaitu mengkonstuksi jawaban informan yang beragam)

Sisil dalam penelitian ini bisa saja memiliki pemikiran dan pemaknaan yang berbeda mengenai seks dalam kehidupannya. Jika kebanyakan orang mencoba menghindari bahasan ini, bahkan dianggap tabu, bagi Sisil seks adalah hal yang baik untuk dibicarakan bahkan dengan terbuka membicarakannya di media sosial. Hal ini tentu saja didasari oleh pertimbangan sehingga dapat menceritakan kehidupan seksnya di media sosial Instagram.

\section{HASIL DAN PEMBAHASAN}

Fenomenologi erat kaitannya dengan epoche selama wawancara terjadi agar terhindar dari bias data, menghilangkan segala pengetahuan dan pengalaman yang sempat dimiliki sebelumnya, dan menjaga peneliti agar tetap netral selama wawancara berlangsung (Kuswarno, 2009:67). Setelah melakukan wawancara, keseluruhan rekaman hasil dari wawancara ditranskripsikan ke dalam tulisan hingga mengklasifikasi pertanyaan-pertanyaan yang telah ditanyakan (Barnawi dan Darojat, 2012: 200).

\subsection{Seksualitas Bukan Lagi Musuh}

Ketika membahas mengenai kebebasan seksual dalam media sosial, seksualitas dalam konstruksi budaya Indonesia seharusnya tidak dibicarakan di tempat umum, terutama yang disampaikan sendiri oleh perempuan. Bukan tanpa sebab, pola pikir patriarki adalah salah satunya (Fadhilah, 2019: 81) serta seksualitas sendiri merupakan suatu produk akhir dari pengawasan dan budaya yang dihidupi dimana maknanya dipengaruhi oleh lingkungan di setiap tempat tinggal (Foucault dalam Fadhilah, 2019:13). Padahal seksualitas seharusnya sudah menjadi komponen penting bagi perkembangan kaum muda karena seksualitas adalah bagian dari dalam diri manusia yang terkait erat dengan kesehatan fisik dan mental Satcher (2001: 356).

Gaya bicara Sisil yang terbilang ceplas-ceplos membuat bahasan di Instagramnya yang mayoritas terkait seksualitas menjadi terdengar vulgar. Pun Melliana (2013: 131) menyampaikan bahwa arti kata seks seakan-akan memiliki pengertian dengan konotasi negatif, maka dari itu Melliana membagi konsep seksualitas menjadi tiga, yaitu seksualitas reproduktif, seksualitas erotis, dan seksualitas gender agar mempermudah dalam memaknainya.

Seksualitas reproduktif fokus pada biologis dan konsep reproduksi, aspek anatomi, seperti menstruasi, kehamilan, aborsi, dan penggunaan alat kontrasepsi (Melliana, 2013: 131). Salah satu seksualitas reproduktif adalah konsep reproduksi dan anatomi, yaitu vagina. Vagina memiliki makna tersendiri bagi perempuan, baik material maupun simbolik (Bell \& Apfel, 1995: 16). Sebagai fungsi reproduktif, vagina berperan besar dalam menghasilkan keturunan sampai pada kelahiran. Sisil memandang kehamilan dan memiliki keturunan adalah sebagai sesuatu yang bukan urgensi karena menurutnya sudah terlalu banyak manusia yang ada di dunia ini. Sisil lebih memilih untuk memelihara anak yang terlahir kurang beruntung, yaitu tanpa orang tua. Hal ini sama dengan yang dijelaskan oleh England, dkk (2016: 13) bahwa banyak perempuan yang sudah aktif secara seksual namun tidak ingin memiliki anak karena alasan personal. Berbicara mengenai berhubungan seksual, Sisil di usianya yang saat itu sedang duduk di bangku kuliah pernah bercerita bahwa terdapat mitos-mitos yang menurutnya aneh dan hanya menimbulkan rasa takut tanpa memahami apa maksud yang sebenarnya. 
Sisil yang memang khas dengan topik pembahasannya terkait seksualitas, ia pun sempat menjelaskan terkait seksualitas reproduktif yang tujuannya mengedukasi pengikutnya di Instagram dengan gaya bicaranya yang tidak menggurui serta menyenangkan. Pada unggahan di atas Sisil menjelaskan macam-macam alat kontrasepsi, seperti pil KB, kondom, implant, suntik, spiral, dan masih banyak lagi. Alat kontrasepsi pada dasarnya dibuat sebagai upaya pemerintah untuk mengendalikan pertumbuhan penduduk melalui program keluarga berencana (Bernardus dalam Herowati dan Sugiharto, 2019: 92). Dalam unggahannya, Sisil menjelaskan pula bahwa beberapa alat kontrasepsi akan membuat nafsu menurun akibat menurunnya kadar testosteron yang dimiliki pula oleh perempuan serta menyarankan untuk menggunakan alat kontrasepsi sesuai anjuran dokter agar sesuai dengan hormon individu.

Seksualitas yang berikutnya, yaitu seksualitas erotis yang mengkhususkan pada rasa nikmat oleh tubuh yang sebenarnya dihasilkan oleh alat kelamin manusia, perilaku atau sikap antar individu dan proses fisiologi yang dapat menciptakan atau bahkan meningkatkan kenikmatan erotis itu sendiri (Melliana, 2013:131). Berbeda dengan seksualitas reproduktif, seksualitas erotis lebih cenderung pada meningkatkan kenikmatan erotis tanpa memikirkan kemungkinan untuk bereproduksi. Dalam kasus ini disebutkan Sicil masturbasi.

Dijelaskan oleh Sisil dalam wawancara personal bahwa masturbasi merupakan bentuk self-care, selflove, dan connecting ourselves dengan cara menyentuh tubuh kita. Tak banyak orang yang mengelak bahwa dirinya sedang melakukan masturbasi, karena mungkin mereka tidak tahu bahwa sebenarnya mereka sedang bermasturbasi. Meskipun masturbasi merupakan tindakan yang seringkali dianggap menyimpang, namun masturbasi memiliki kekuatan untuk mempengaruhi keintiman dengan orang lain bahkan diri sendiri. Masturbasi membuat seseorang belajar tentang respons dan kesenangan seksual diri sendiri serta tentang rasa otonomi tubuh yang dapat meningkatkan kualitas kepercayaan diri seseorang. Masturbasi bisa menjadi jalan untuk memberikan pengalaman keintiman yang positif dan meningkatkan kepuasaan seksual (Coleman, 2002: 9).

Sisil menganggap bahwa dengan masturbasi merupakan bagian dari dirinya yang tidak mungkin lepas. Sisil mengaku tidak berhubungan seksual sejak November 2020, namun tak menjadi masalah bagi dirinya karena dengan masturbasi, ia menjadi tahu bagaimana cara membuat dirinya bahagia dan memahami bagian tubuh mana yang baginya memberikan kenikmatan sesuai dengan yang dijelaskan oleh Mulia (2015: 14) bahwa seksualitas merupakan bentuk komunikasi intim dengan diri sendiri dan dengan orang lain, apapun jenis kelamin atau gendernya. Dari pengakuannya yang menyebutkan bahwa Sisil sudah tidak memerlukan laki-laki sebagai pemuas dirinya, ini berarti Sisil menganggap bahwa ia sudah bisa mandiri untuk memberi kepuasan akan dirinya, sehingga tidak perlu lagi laki-laki untuk memberi kepuasan pada dirinya.

Melliana (2013:132) menjelaskan konsep seksualitas yang ketiga, yaitu seksualitas gender yang fokus pada pembagian sosial atau sistem klasifikasi manusia menurut jenis kelaminnya. Seksualitas gender berbicara tentang bagaimana seksualitas dan gender dipandang sebagai peran gender dalam kehidupan seseorang dan mempengaruhi persepsi orang lain tentang seksualitas mereka. Gender bukan merupakan sesuatu yang kita bawa dari lahir serta bukan sesuatu yang kita miliki, namun gender adalah sesuatu yang kita lakukan dan tunjukkan sebagai hasil dari konstruksi sosial (Muhammad, 2011:11).

Dalam aktivitasnya di Instagram, Sisil juga kerap membahas terkait topik seksualitas gender ini. Sebenarnya topik ini banyak dibicarakan di media sosial Instagramnya, namun biasanya tidak dalam satu konten tersendiri. Berikut adalah salah salah satu konten yang terkait seksualitas gender.

Kata 'gender' sering disalahartikan sebagai jenis kelamin. Padahal konsep gender sesungguhnya memiliki pengertian yang berbeda. Jenis kelamin menuju pada konteks biologis seperti penis dan vagina, namun gender merupakan konstruksi sosial (Muhammad, 2011:11). Unggahan Sisil di atas dengan narasi yang berbunyi tentang bagaimana perempuan dianggap 'nakal' atau 'bad girl' jika telah meniduri beberapa laki-laki. Stigma ini terus menempel hingga secara tidak sadar, sebagai wanita pun menyetujui stigma tersebut dan menormalisasi apabila pelakunya adalah laki-laki.

Sisil bercerita bahwa tiga tahun lalu dirinya pernah bertemu dengan laki-laki yang mencoba mendekatinya hingga mengajak Sisil untuk berkomitmen. Setelah banyak berbicara dan bercerita, laki-laki itu bertanya, "Kamu sudah pernah tidur dengan berapa laki-laki?". Tidur yang dimaksudkan disini adalah berhubungan seksual. Awalnya ragu harus menjawab bohong atau jujur, karena menurut Sisil ini merupa- 
kan pertanyaan jebakan. Setelah memutuskan, Sisil memutuskan untuk menjawabnya dengan jujur, "I had sex with nine guys before you". Terkejut, lakilaki itu langsung mengatai Sisil sebagai pelacur karena telah tidur dengan sembilan laki-laki. Dari sini dapat dilihat bagaimana stigma gender sangat menempel. Peristiwa ini disebut dengan double standard, dimana perempuan yang telah melakukan hubungan seksual dengan banyak laki-laki disebut sebagai pelacur serta stigma buruk lainnya, sedangkan laki-laki yang telah melakukan tidur dengan banyak perempuan malah disebut sebagai laki-laki jantan dan perkasa (Endendijk, 2020:184). Dalam aktivitasnya mengungkapkan diri, dapat dilihat bahwa aktivitasnya mengungkapkan diri dapat dimaknai sebagai bentuk ekspresi dirinya dan tidak melihat pengungkapan diri sebagai hal memalukan.

\subsection{Bukan Waktunya Untuk Diam Saja}

Self-disclosure sebagai salah satu aspek penting dalam komunikasi karena melibatkan adanya suatu pengungkapan terkait diri sendiri yang bersifat pribadi atau bahkan sebelumnya tidak ada yang mengetahui (Devito, 1997: 61). Self-disclosure yang biasanya diungkapkan kepada seseorang secara faceto-face, dengan kehadiran internet terutama media sosial menjadikan pengungkapan diri dapat terjadi di mana saja bahkan topik apa saja.

Ketika dikaitkan dengan penggunaan media sosial, informasi pengungkapan diri kini semakin luas dan beraneka ragam, bahkan penerimanya pun semakin luas tidak sebatas satu atau dua orang (Taylor dalam Al-Kandari, 2016:85). Setiap orang yang melakukan pengungkapan diri memiliki maknanya masingmasing akan informasi pengungkapan dirinya. Hal inilah yang kemudian menjadi benang merah dalam penelitian ini, yakni pemaknaan terkait seksualitas hingga berani untuk mengungkapkannya di media sosial Instagram @ sisilism.

Topik seksualitas yang cenderung ditutupi dan enggan untuk dibicarakan bagi sebagian orang terutama perempuan (Greene \& Faulkner, 2005: 249), sementara Sisil membagikan informasi tentang dirinya dengan terbuka. Informasi yang dibagikan di Instagram pada umumnya akan dapat dibaca oleh seluruh pengguna Instagram (Budiargo, 2015:48), itu berarti informasi tentang seksualitas pada akun Instagram Sisil dapat diperoleh dengan mudah dan dapat dibaca oleh siapapun bagi pengguna media sosial Instagram. Berdasarkan pengamatan peneliti selama wawancara berlangsung, Sisil dalam mem- bagikan informasi akan dirinya jika dimasukkan ke dalam Johari Windows, dapat dikategorikan sebagai open area, yaitu seseorang yang terbuka akan dirinya sendiri, maupun orang lain.

“......walaupun itu orang asing gitu, karena gue punya support kayak my close circle itu sangat ngesupport gue banget. Ketika orang lain ngebenci gue, yaudah toh temen ....." (Sisil, 18/2/21).

Sisil dengan karakter dirinya yang masuk ke dalam open area pada Johari Window, menjelaskan bahwa yang membuat dirinya untuk berani terbuka dengan banyak orang adalah karena dirinya sendiri tumbuh dan berkumpul dengan orang-orang yang saling terbuka pula karena sebuah hubungan pertemanan itu sangat penting dalam pembentukan diri (Gottman dalam Bartels, 2019: 2).

DeVito (1997:61) menjelaskan bahwa pengungkapan diri dapat diawali dengan adanya keterbukaan dimana individu mendapatkan tempat bagi dirinya untuk didengar, dimengerti, dipahami, dan diberi tanggapan oleh orang lain akan sesuatu hal yang terjadi pada dirinya. Itulah yang terjadi pada Sisil berdasarkan penjelasan di atas, bahwa ia telah merasa didengar, dimengerti, dipahami, dan diberi tanggapan oleh teman sepermainannya sehingga ia merasa nyaman untuk melakukan pengungkapan diri.

Sudah menjadi risiko untuk menjadi content creator bila mendapat tanggapan buruk (Dawson, 2018: 3) akan apa yang ditampilkan pada halamannya. Namun pribadi dan karakter Sisil yang santai, membuat aktivitas pengungkapan dirinya di Instagram menjadi lebih mudah untuk dilakukan, terutama bila dirinya menerima tanggapan buruk, baik dari keluarganya maupun dari sesama pengguna Instagram. Namun memang tidak bisa dipungkiri bahwa dulunya perasaan takut pasti ada, karena tentu saja yang Sisil tampilkan di Instagramnya memang bahasan yang tidak banyak orang bahas.

"Memang ada yang akhirnya ngatain gue sebagai ancaman dan bahaya buat masa depan negara-lah, bahkan ada yang sampai nanyain alamat gue, tapi fast forward 2021 nggak ada tuh yang ngedatengin gue. Mereka beraninya ngatain di sosmed doang, in reality? Nobody knows you" (Sisil, 16/2/21).

Kalimat ini Sisil ungkapkan dengan sangat santai terucap dari bibirnya. Ia yang dulu merasa ketakutan akan apa yang lakukan, kini kalimat dan ancaman itu hanya hiburan baginya dan bukan sesuatu yang besar 
untuk dikhawatirkan. Tidak banyak orang yang dapat melewati masa seperti ini, terutama harus tenang dalam ancaman. DeVito (2013: 66) memaparkan bahwa kepribadian menjadi dua yaitu ekstrover dan introver. Pemilik kepribadian ekstrover adalah mereka yang cenderung terbuka, santai, dalam memberikan informasi. Walaupun informasinya akan membahayakan diri mereka sendiri, pemilik kepribadian ekstrover akan tetap terbuka dan santai dalam aktivitas pengungkapan dirinya.

Pengungkapan diri terkait seksualitas di media sosial Instagramnya@sisilism mendapatkan respon yang baik dari pengikutnya. Informasi yang awalnya Sisil rasa akan mendapatkan ancaman dan membahayakan, nyatanya diterima baik oleh pengikutnya. Tanggapan yang baik dari pengikutnya membuat Sisil merasa dihargai, mau didengar, dan diterima dengan baik. Sama seperti apa yang dikatakan oleh Derlega (dalam DeVito, 1997:62) bahwa ketika pengungkapan diri dilakukan pada orang yang kita percayai dan orang tersebut juga, nantinya akan menimbulkan rasa aman, nyaman, dan memperkuat perilaku pengungkapan diri.

Dalam aktivitasnya pengungkapan diri di media sosial nyatanya memberikan pengaruh bagi pengikutnya untuk ikut melakukan pengungkapan diri. Aktivitas ini dituangkan dalam unggahannya yang berjudul Big Sis Advice dan memberikan dampak positif bagi pengikut lainnya saat ini karena pada akhirnya mereka akan saling belajar dari ketidaktahuan masing-masing. Self-disclosure yang dilakukan di media sosial tentu saja tidak selalu menghasilkan respon yang baik serta positif, namun tentu akan ada pihak-pihak tertentu yang tidak setuju, terutama dalam hal ini konteks yang dibicarakan adalah mengenai seksualitas. Tentu saja banyak bermunculan diskriminasi dan kemarahan yang muncul dari pihak lain.

Dalam penelitian ini, peneliti menemukan bahwa kepribadian yang melekat dalam diri Sisil adalah seseorang yang ekstrovert, dimana ia senang untuk bercerita dan mudah untuk terbuka dengan orang lain. Dari kepribadiannya ini, besaran kelompok dalam melakukan pengungkapan diri tidak mempengaruhi seberapa banyak informasi yang akan dia ceritakan. Bahkan, di media sosial yang penggunanya sangat besar, Sisil masih bisa bercerita tentang pengalaman seksualitasnya. Hal ini dikarenakan pula adanya rasa saling menyukai antara Sisil dan pengikutnya di Instagram sehingga menimbulkan efek diadik, dimana pengikutnya pun ikut saling bercerita mengenai pengalamannya.

Pengungkapan diri tidak luput dari adanya risiko yang harus diterimanya. Bochner (dalam DeVito, 2013: 69) menjelaskan adanya risiko tersebut, risiko pertama adalah penolakan dari pribadi dan sosial. Berdasarkan cerita yang disampaikan oleh Sisil dari pengalamannya, penolakan ini ia rasakan pada awal dirinya melakukan pengungkapan diri pada tahun 2018. Penolakan keluarga sangat ia rasakan, mulai dari sindiran dan koneksi relasi keluarga yang semakin renggang. Namun walaupun respon negatif yang muncul dari keluarganya saat itu, Sisil tidak menjadi benci akan keluarganya karena sudah saling sibuk dengan urusan masing-masing.

Risiko yang kedua adalah kerugian material. Dari temuan peneliti, Sisil yang membahas seksualitas di Instagramnya sempat mengalami kerugian material.

"Jadi waktu itu gue pernah Instagram gue pernah di-banned gitu kan yang pertama kali tahun 2019 akhir. Fyi, yang kemaren barusan itu kena banned yang kedua kali gara-gara mass report hahaha. Bahkan gue tuh ngerasa at this point, gue udah ngerasa yaudahlah, ke banned lagi-ke banned lagi. Mau gimana lagi? Cuma ya capek sih sebenernya. Soalnya sebenernya gue lagi proses bikin institusi yang fokusnya ke edukasi seks. Cuma dengan keadaan sosmed gue yang sering ke banned gini, gue jadi bingung mau cari massa lagi, mulai dari nol lagi, ngenalin lagi. Tapi kalo udah punya angka yang gede, akan lebih mudah buat ngedapetin massa untuk bikin webinar nantinya. Gue hidup juga salah satunya dari webinar yang gue bikin, tapi kalo di-banned terus, gue tekor lama-lama" (Sisil, 16/2/21).

Pada penelitian ini, peneliti menemukan adanya kerugian material yang dialami Sisil karena unggahannya yang membahas seksualitas. Seksualitas yang masih dianggap tabu dijadikan sasaran empuk bagi beberapa pihak kontra akan hal ini. Sisil mengalami akun Instagramnya@sisilism diblokir oleh pihak Instagram karena dilaporkan oleh orang-orang yang kontra akan bahasannya. Tentu hal ini memberi dampak buruk bagi Sisil yang menjadikan content creating sebagai pekerjaannya. Risiko yang ketiga adalah kesulitan antarpribadi. Bila melihat audiens media sosial yang sangat besar, tentu saja akan ditemukan penolakan-penolakan setelah mendengar pengungkapan diri Sisil. 
"Kalo lo mau baca satu-satu, pasti memang ada komen jelek di postingan gue. Pasti ada orang yang menolak, karena gue paham nggak semua orang bisa mikir yang sama. Tapi gue nggak mau memberikan energi gue ke hal-hal seperti itu yang akhirnya bikin down dan segala macem." (Sisil, 16/2/21).

Peneliti melihat adanya risiko yang dialami Sisil ketika melakukan pengungkapan diri di media sosial. Namun seperti yang telah disampaikan sebelumnya bahwa orang-orang yang menolaknya di media sosial, sebenarnya mereka hanya sekadar berkomentar di dunia maya dan tidak berpengaruh dan tidak merugikan akan kehidupan Sisil di dunia nyata.

\subsection{Batasan Dalam Bermedia Sosial}

Pada sub bab yang ketiga ini nantinya akan menjelaskan bagaimana batasan yang dibangun oleh Sisil sebagai pemilik informasi kepada media sosial Instagramnya. Seperti yang telah disebutkan dalam bab dua terkait perspektif teoretis bahwa dalam pengungkapan diri erat kaitannya dengan boundaries atau batasan yang dimiliki oleh communication privacy management (CPM). Batasan ini juga menentukan sedalam apa atau seberapa banyak informasi yang akan dibagikan Sisil pada Instagramnya. Ukuran batasan ini beragam dipengaruhi oleh berbagai sebab.

Saat pertama kali bertemu dengan Sisil, peneliti amat yakin bahwa Sisil ini memiliki kepribadian yang terbuka dan cenderung ekstrovert. Benar saja saat diwawancarai, Sisil dengan kepribadiannya yang ramah, menjawab semua pertanyaan dengan sangat santai.

"I feel like gue udah ngerasa nyaman sama diri gue dan gue nggak pernah ngerasa, kenapa harus ditutup-tutupin? Kenapa harus punya dua personality? Ada kan orang yang nge-fake gitu. Jadi di depan tuh famous yang alim gitu tapi di belakang dia punya sifat lain. Kalo gue ya, this is me. Gue terlalu capek buat pretending dan I'm an open book ya. Kalo orang mau tau tentang gue yang bener-bener pengen tau, bukan sekadar kepo yaa. Apalagi nantinya informasi gue bakal dipake yang enggak-enggak, ya gue nggak masalah. Gue mah open-open aja." (Sisil, $16 / 2 / 21$ ).

Sisil menjelaskan bagaimana ia sudah nyaman akan dirinya sehingga ia tidak perlu lagi untuk berusaha menutupi segala informasi yang ia miliki. Seksualitas yang masih banyak orang pikir sebagai informasi yang rahasia, malah ia ceritakan di media sosialnya sebagai media edukasi. Batasan-batasan yang di- bangun oleh pemilik informasi dipengaruhi oleh berbagai macam faktor, mulai dari konteks pengungkapan, kedekatan, dan lainnya.

Walaupun kepribadiannya yang terbuka, namun tetap saja ada informasi yang tidak bisa ia bagikan di media sosial Instagramnya. Dari berbagai macam informasi yang telah ia bagikan. Sisil merasa nama lengkapnya merupakan salah satu informasi yang tidak perlu ia bagikan di Instagram. Terdengar remeh, namun Sisil menganggap bahwa nama lengkapnya tidak cukup penting untuk diketahui oleh banyak orang dikarenakan oleh penyebutan nama lengkapnya yang sulit.

"Nama gue itu susah. Tapi kalo misalnya ada orang tau juga nggak masalah, maksudnya gue nggak ngerasa penting buat ngumumin nama lengkap gue aja. Toh nama Sisil lebih mudah disebut dan diingat juga." (Sisil, 16/2/21).

Selain nama lengkap, pun Sisil tidak merasa perlu untuk menginformasikan tahun berapa ia lahir, dari jurusan dan universitas apa ia lulus, hingga kehidupan pribadinya terkait pacar atau partner yang sedang ia miliki.

Sisil yang sudah lama hidup berpisah dengan orang tua, menganggap pula informasi terkait keluarga besarnya tidak perlu untuk ia bawa ke media sosial. Hal ini diakibatkan karena selain tidak terlalu penting baginya dan tidak ada korelasinya dengan konten yang sedang ia buat, Sisil memang sudah lama tidak bertemu keluarganya termasuk pada hari-hari besar.

"Bahkan gue udah nggak pernah lagi ngumpul bareng keluarga besar gue ketika lebaran. Gue udah dua tahun nggak ikut lebaran karena gue tinggal di Bali. Terus kaya emang males. Karena menurut gue kaya sama aja, lebaran kaya gitu-gitu aja. Kaya fake lah. Kaya pretending aja, orang sebelumnya juga ga pernah kumpul sama keluarga. Jadinya kaya sematamata karena lebaran aja makanya semuanya harus ngumpul. Sebenernya gue biasa-biasa aja sama keluarga besar gue. Nyokap gue juga pernah bilang ke gue, kalo nggak pernah bilang ke mbah uti atau kayak ke kakek nenek sama keluarga besar gue soal apa yang gue kerjain. Terus gue kaya, oh kaya gue nggak mau pamer kerjaan gue. Kalo mereka ngeliat Instagram gue dan tau, yaudah bodo amat, biarin" (Sisil, $16 / 2 / 21$ ).

Hubungannya dengan keluarganya pun sudah sedikit merenggang, hingga apa yang ia lakukan di media sosial dahulu sempat menjadi obrolan di keluarga besar. 
"Nyokap gue dulu, kayaknya sekitar dua tahun lalu pernah bilang gini, "Kak kayaknya udah jangan posting-posting kaya gitu lagi. Bahas-bahas tentang seks, soalnya ini kamu diomongin sama si tante A lho, tadi mama abis ketemu dia." Terus ya gue bilang, "Yaudah sih biarin aja. Orang itu kerjaan aku. Mau gimana?" Tapi itu kejadian dua tahun lalu sih. Kalo sekarang gue nggak tau karena mereka pada sibuk sama keluarganya masing-masing dan emang basically keluarga gue bukan keluarga yang deket banget sampe sering kumpul. Kayaknya mereka udah pada bodo amat. Hahaha baguslah." (Sisil, 16/2/21).

Sisil mengaku bahwa hubungannya dengan keluarga besarnya tidak terlalu dekat, bahkan yang biasanya Hari Raya Idul Fitri digunakan sebagai sarana berkumpul dengan keluarga, nyatanya keluarganya tidak melakukan tradisi itu dan sibuk dengan urusannya masing-masing.

Berbicara mengenai informasi yang dibagikan melalui media sosial Instagram tentunya informasi akan dimiliki oleh banyak orang, baik sebagai pengikut atau bukan. Risiko tersebarnya informasi akan semakin besar bahkan bisa disalahgunakan. Risiko menjadi content creator memang sangatlah besar terutama karena pengguna media sosial Instagram yang sangat beragam. Dalam membuat batasanbatasan informasi harus ditegaskan. Sisil menjelaskan bahwa batasan yang ia miliki sebenarnya tidak terlalu tebal karena kepribadiannya yang terbuka dan senang bercerita. Namun, memang ada informasi-informasi sensitif serta membahayakan yang tidak bisa ia sampaikan di media sosial terutama kaitannya pembahasan topik seksualitas.

Sisil dengan keputusannya untuk tidak memberikan informasi akan dirinya di media sosial Instagram menggambarkan bahwa dirinya memiliki batasanbatasan tertentu untuk beberapa informasi. Keluarga bagi Sisil masih merupakan sesuatu yang privasi bagi dirinya.

\section{KESIMPULAN}

Pengalaman dari subjek terkait seksualitas menunjukkan bahwa seksualitas memiliki peran penting dalam hidupnya. Sisil menganggap seksualitas adalah sesuatu yang indah, bahkan dapat menciptakan cinta kasih pada setiap pelakunya selama dilakukan secara konsensual dan menyetujui untuk melakukan hal itu. Sisil mendukung adanya kebebasan seksual karena ia menganggap setiap orang memiliki seksualitas yang berbeda-beda. Sisil memandang seksualitas sebagai kesenangan dan kenikmatan sehingga ia berani melakukan pengungkapan diri dengan menceritakan pengalaman seksualitasnya di media sosial.

Sisil melakukan pengungkapan diri, terutama munculnya efek diadik dimana aktivitasnya melakukan pengungkapan diri yaitu mengajak orang lain pula untuk melakukan pengungkapan diri lewat media sosial Instagramnya. Sisil dengan kepribadiannya yang terbuka, lewat pengungkapan diri, ia merasa nyaman karena telah berhasil jujur akan apa yang ia rasakan dan berhasil ia ceritakan kepada orang lain.

Dari pengalaman pengungkapan diri yang dilakukan Sisil di media sosial Instagramnya, Sisil memaknai hal tersebut sebagai kepuasan dirinya untuk berbagi dan bercerita akan pengalaman yang ia alami, bahkan yang pengikutnya alami. Sisil tidak memandang seksualitas adalah sesuatu yang harus ditutupi, melainkan harus dibicarakan sebagai bentuk edukasi pribadi dan harus dibagikan kepada orang lain sebagai sebuah pembelajaran

\section{DAFTAR PUSTAKA}

Acquisti, A. dan Gross, R. (2006). Imagined Communities: Awareness, Information Sharing, and Privacy on the Facebook. Paper yang disajikan oleh International Workshop on Privacy Enhancing Technologies, Germany: Springer.

Adilah, Y, dkk. (2017) Determinan Penggunaan Kondom pada Hubungan Seksual Pertama Kali oleh Remaja Belum Menikah di Indonesia. Jurnal Ilmu Kesehatan Masyarakat, 8(2), 91-99.

Al-Kandari, A., Melkote, S. R., \& Sharif, A. (2016). Needs and Motives of Instagram Users that Predict Self-disclosure Use: A Case Study of Young Adults in Kuwait. Journal of Creative Communications, 11 (02), 85-101.

Andarmoyo, S. (2012). Psikososial dalam Pendekatan Konsep dan Proses Keperawatan. Yogyakarta: Ar-Ruzz Media.

Arafat, I. S., \& Cotton, W. L. (1974). Masturbation practices of males and females. The Journal of Sex Research, 10(4), 293-307.

Arikunto, S. (2010). Prosedur Penelitian Suatu Pendekatan Praktik. Jakarta: PT Rineka Cipta.

Astuti, Prida Ariani Ambar, dkk. (2011). Remaja Digital: Learn, Play, Socialize, Participate. Surakarta: Universitas Muhammadiyah Surakarta.

Ayub, K., Maulina, N., \& Alif, M. (2017). Self Disclosure Chef Agus Sasirangan di Media Sosial Instagram. MetaCommunication: Journal of Communication Studies, 01 (02), 01-09. 
Barnawi dan Darojat, J. (2018). Penelitian Fenomenologi Pendidikan: Teori dan Praktik. Yogyakarta: Ar-Ruzz Media.

Bartels, J., dkk. (2019). My Colleagues Are My Friends: The Role of Facebook Contacts in Employee Identification, Management Communication Quartely, 00(0), 1-22.

Bell, S. E., \& Apfel, R. J. (1995). Looking at bodies: Insights and inquiries about DES-related cancer. Qualitative Sociology, 18(1), 3-19.

Braun, V., \& Wilkinson, S. (2001). Socio-cultural Representations of The Vagina.

Budiargo, D. (2015). Berkomunikasi ala Net Generation. Jakarta: PT Elex Media Komputindo Kompas Gramedia.

Coleman, E. (2002). Masturbation as a means of achieving sexual health. Journal of Psychology \& Human Sexuality, 14(2), 5-16.

Dawson, V. R. (2018). Fans, Friends, Advocates, Ambassadors, and Haters: Social Media Communities and the Communicative Constitution of Organizational Identity, Social Media + Society, 4(1), 1-11.

Debatin, B., Lovejoy, J. P., Horn, A., dan Hughes, B. N. (2009). Facebook and Online Privacy: Attitudes, Behaviors, and Unintended Consequences. Journal of Computer-Mediated Communication, 15 (1), 83-108.

Devito, J. A. (1997). Komunikasi Antarmanusia. Jakarta: Professional Books. Devito. J. A. (2013). The Interpersonal Communication Book 13th Edition. USA: Pearson Education.

Djik, Jan Van. (1999). The Network Society. California: SAGE.

Endendijk, J. J., dkk. (2020). He is a Stud, She is a Slut! A Meta-Analysis on the Continued Existence of Sexual Double Standards, Personality and Psychology Review, 24(2), 163-190.

Fromm, Erich. (2007). Cinta, Seksualitas, dan Matriarki. Yogyakarta \& Bandung: Jalasutra.

Greene, K., \& Faulkner, S. L. (2005). Gender, belief in the sexual double standard, and sexual talk in heterosexual dating relationships. Sex Roles: A Journal of Research, 53(3-4), 239-251.

Herowati, Diyah dan Sugiharto, Mugeni. (2019) Hubungan antara Kemampuan Reproduksi, Kepemilikan Anak, Tempat Tinggal, Pendidikan, dan Status Bekerja pada Wanita Sudah Menikah dengan Pemakaian Kontrasepsi Hormonal di Indonesia Tahun 2017. Buletin Penelitian Sistem Kesehatan, 22 (2), 91-98.

Joinson, A., Houghton, D. J., Vasalou, A., dan Marder, B. L. (2011). Digital Crowding: Privacy, Self-disclosure, and Technology. Dalam Sabine
Trepte dan Leonard Reinecke (eds), Privacy Online: Perspectives on Privacy and Self-disclosure in the Social Web (pp. 33-46). Hamburg: Springer

Journal of Reproductive and Infant Psychology, 19(1), 17-32. Chennamaneni, A. dan Taneja, A. (2015). Communication Privacy Management and Self-disclosure on Social Media - A Case of Facebook. Paper yang disajikan di Twenty-first Americas Conference on Information System, Puerto Rico.

Kementerian Kesehatan Republik Indonesia. Statistik kasus HIV/AIDS di Indonesia dilapor sampai Desember 2011. Jakarta: Kementerian Kesehatan Republik Indonesia Direktorat Jenderal Pengendalian Penyakit dan Penyehatan Lingkungan; 2011

Kuswarno, E. (2009). Metode Penelitian Komunikasi Fenomenologi Konsepsi, Pedoman, dan Contoh Penelitiannya. Bandung: Widya Padjajaran.

Mahardika, R. D. \& Farida. (2019). Pengungkapan Diri pada Instagram Instastory.

Jurnal Studi Komunikasi, 03 (01), 101-117.

Miles, J. G. (2014). Instagram Power: Build Your Brand and Reach More Customers with the Power of Pictures.USA: McGraw-Hill Education.

Moore, S. G., Dahl, D. W., Gorn, G. J., \& Weinberg, C. B. (2006). Coping with condom embarrassment. Psychology, Health \& Medicine, 11(1), $70-79$.

Moleong, L. J. (2012). Metodologi Penelitian Kualitatif. Bandung: PT Remaja Rosdakarya.

Mulia, M. (2015). Mengupas Seksualitas. Jakarta: Opus Press.

Muhammad, Husein, dkk. (2011) Fiqh Seksualitas: Risalah Islam Untuk Pemenuhan Hak-Hak Seksualitas. Jakarta: BKKBN.

Munfarida, Elya. (2009). Kritik Wacana Seksualitas Perempuan. Jurnal Studi Gender \& Anak, 4 (1), 122-139.

Nasrullah, Rulli. (2017). Media Sosial Perspektif Komunikasi, Budaya dan Sosioteknologi. Bandung: Simbiosa Rekatama Media.

Nasrullah, Rulli. (2018). Komunikasi Antar Budaya: Di Era Budaya Siber. Jakarta: Prenada Media.

Negara, O. (2005). Seksualitas. Jurnal Perempuan, 41 (2), 7-22.

Nurhadi, Zikri F. (2015). Teori-teori Komunikasi: Teori Komunikasi dalam Perspektif Penelitian Kualitatif. Bogor: Ghalia Indonesia.

Raharjo, Y. (1997). Seksualitas Manusia dan Masalah Gender: Dekonstruksi Sosial dan Reorientasi. Populasi, 08 (01), 55-61. 
Rakhmat, Jalaludin. (2011). Psikologi Komunikasi. Bandung: PT. Remaja Rosdakarya.

Rohmadi, M. dan Wijana, I Dewa P. (2013). Sosio Linguistik Kajian Teori dan Analisis. Yogyakarta: Pustaka Pelajar.

Romo, L. K., Thompson, C. M., dan Donovan, E. E. (2017). College Drinkers' Privacy Management of Alcohol Content on Social-Networking Sites. Communication Studies, 68 (2), 173-189.

Satcher, D. (2001). The Surgeon General's Call to Action to Promote Sexual Health and Responsible Sexual Behavior. American Journal of Health Education, 32 (6), 356-368.

Satori \& Komariah. (2017). Metodologi Penelitian Kualitatif. Bandung: Alfabeta.

Seidman, I. (2006). Interviewing as Qualitative Research: A Guide for Researchers in Education and the Social Sciences. USA: Teachers College Press.

Supratiknya. (1995). Komunikasi Antarpribadi. Yogyakarta: Penerbit Kanisius.

Sprecher, S., Treger, S., dan Wondra, J. D. (2012). Effects of Self-disclosure Role on Liking, Closeness, and Other Impressions in Get-acquainted Interactions. Journal of Social Personal Relationships, 30, 4, 497-514.
Syukur, Y. (2014). Open Booking Online (BO): Prostitusi di Facebook dalam Tinjauan Antropologi Simbolik, Jurnal Studi Pemuda, 3(2), 8998.

Petronio, S. (2002). Boundaries of Privacy: Dialectics of Dsclosure. USA: State University of New York.

Verklan, M. T., (2007). Johari Window: A Model for Communicating to Each Other. Journal of Perinatal \& Neonatal Nursing, 21, 02, 173-174.

Wardhaugh, R. (2006). An Introduction to Sociolinguistics. Australia: Blackwell Publishing.

Warner, Lee, dkk. (2004) Condom Effectiveness for Reducing Transmission of Gonorrhea and Chlamydia: The Importance of Assessing Partner Infection Status, American Journal of Epidemiology, 159 (3), 242-251.

West, R. danTurner, Lynn H. (2007). Introduction Comunication Theory: Analysis and Application, 3rd Edition. New York: McGraw Hill.

West, R. an Turner, Lynn H. (2010). Introduction Cmmunication Theory: Analysis and Application, 4th Edition. New York: McGraw Hill.

Zhang,R. \& Fu, Jiawei S., (2020). Privacy Management and Self-Disclosure on Social Network Sites: The Moderating Effects of Stress and Gender. Journal of Computer-Mediated Communication, 25 (03), 236. 